\title{
ERRATUM
}

John Nádas and Andreas Janke (eds.), The San Lorenzo Palimpsest: Florence, Archivio del Capitolo di San Lorenzo, Ms. 2211, vol. 1: Introductory Study; vol. 2: Multispectral Images, Ars Nova, n.s. 4 (Lucca: Libreria Musicale Italiana, 2016). xiii pp.+ 123 fols (135 fols including blanks). $€ 300$. ISBN 978887096852 1. ERRATUM

\section{MARGARET BENT}

https:/ / doi.org/10.1017/S0961137117000092. Published by Cambridge University Press, 11 October 2017.

In PMM 26/2 (October 2017), the title of the first book, reviewed by Margaret Bent, was wrongly printed. The correct heading should be as follows:

John Nádas and Andreas Janke (eds.), The San Lorenzo Palimpsest: Florence, Archivio del Capitolo di San Lorenzo, Ms. 2211, vol. 1: Introductory Study; vol. 2: Multispectral Images, Ars Nova, n.s. 4 (Lucca: Libreria Musicale Italiana, 2016). xiii pp.+ 123 fols (135 fols including blanks). €300. ISBN 9788870968521.

This error has now been rectified in the online version of the article.

\section{Reference}

Bent, M. (2017) John Nádas and Andreas Janke (eds.), The San Lorenzo Palimpsest: Florence, Archivio del Capitolo di San Lorenzo, Ms. 2211, vol. 1: Introductory Study; vol. 2: Multispectral Images, Ars Nova, n.s. 4 (Lucca: Libreria Musicale Italiana, 2016). xiii pp.+ 123 fols (135 fols including blanks). €300. ISBN 978887096852 1. Plainsong and Medieval Music. 26(2), 186-198. 